\title{
PRINCIPAIS ZOONOSES EM PEQUENOS ANIMAIS: BREVE REVISÃO
}

\author{
Mayra de Castro Ferreira Lima ${ }^{1}$ \\ Joyce Cappa Mittestainer ${ }^{1}$ \\ Paula Barreto da Rocha ${ }^{1}$ \\ Elisabeth Regina de Carvalho ${ }^{1}$ \\ Barbara do Prado Verotti ${ }^{1}$ \\ Patricia Rosa Pellicciari ${ }^{1}$ \\ Cassiano Victoria ${ }^{2}$ \\ Helio Langoni ${ }^{2}$
}

\section{RESUMO}

Com a relação mais estreita entre as pessoas e os animais, as zoonoses se tornam mais importantes na saúde pública. Entre elas, podem ser destacadas a raiva, leishmaniose, brucelose canina, febre maculosa, toxoplasmose e leptospirose que apresentam aspectos epidemiológicos e de controle diferentes entre elas. A Raiva é $100 \%$ fatal em animais e humanos, causando encefalomielite aguda e sendo considerada ainda um grave problema de saúde pública. Desde as décadas de 1950 e 1960, quando houve elevado número de casos de raiva humana transmitida principalmente por cães no Brasil, pôde-se observar uma preocupação nas atividades governamentais, como, por exemplo, a implantação do "Programa Nacional de Profilaxia da Raiva Humana" (PNPR) em 1973, a nível nacional, e, posteriormente, em 1983, o "Plano de Ação para Eliminação da Raiva Urbana das Principais Cidades da América Latina", desenvolvido pela Organização Pan-Americana da Saúde (OPAS). Alguns avanços foram obtidos no controle dessa doença, com redução do número de casos humanos, tendo sido reportado apenas um caso de raiva humana no Brasil em 2015. A Leishmaniose Visceral Canina (LVC) vem se expandindo no Brasil, sendo uma zoonose de extrema importância para a saúde pública. Seu agente etiológico é um protozoário do gênero Leishmania, transmitido pela picada de mosquitos flebotomíneos. Os cães são os principais reservatórios primários da doença, enquanto os humanos, os hospedeiros acidentais. Esta doença em cães traz muita polêmica, já que o Ministério da Saúde juntamente com o Ministério da Agricultura Pecuária e Abastecimento (MAPA) criaram a Portaria Interministerial $n^{\circ} 1426$ que pró́be seu tratamento com produtos de uso humano ou não registrados no MAPA, recomendando a eutanásia dos cães infectados ou doentes. A Brucelose canina é caracterizada como uma antropozoonose infecciosa crônica, que apesar de menor incidência na população humana, possui grande importância socioeconômica, pois é a principal causa de infertilidade em canídeos domésticos em todo o mundo e trata-se de uma zoonose ocasional, mesmo no caso da doença em cães que pode infectar humanos em suas atividades laborais, principalmente no caso de cães de canil. A Febre maculosa brasileira é causada pela bactéria gram negativa, intracelular obrigatória, Rickettsia rickettsii, tendo como vetor o carrapato Ixodideo Amblyomma cajennense. Com a proximidade das áreas urbana e rural, a incidência da doença em humanos tem aumentado, já que a exposição ao vetor e aos animais infectados ou doentes é cada vez mais frequente. A doença tem evolução aguda e seu diagnóstico rápido é importante, pois pode ser fatal na maioria dos casos, se não houver a instituição do tratamento rapidamente. A Toxoplasmose é uma das zoonoses de ampla difusão mundial, causada pelo protozoário Toxoplasma gondii, que apresenta três genótipos distintos. Tem como hospedeiro definitivo o gato e outros felídeos e, devido à crescente

\footnotetext{
${ }^{1}$ Alunos da disciplina "Saúde pública individual e coletiva para o Sistema Único de Saúde" do Programa de Residência Multiprofissional em Saúde MS/MEC - FMVZ - UNESP, Campus de Botucatu.

${ }^{2}$ Docente do Departamento de Higiene Veterinária e Saúde Pública - FMVZ - UNESP, Campus de Botucatu.
} 
importância como animal de estimação, há a necessidade de maiores esclarecimentos sobre sua transmissão, especialmente quando há o envolvimento de gestantes. Há conceitos controversos e errôneos sobre o contato direto com esses animais e a sua transmissão. Precários hábitos de higiene e ingestão de alimentos crus são as principais fontes de contaminação em humanos e, desta forma, profissionais da saúde devem orientar a população quanto às medidas essenciais de higiene para diminuir sua incidência. A Leptospirose é outra zoonose de distribuição mundial causada principalmente pela bactéria Leptospira interrogans e afeta diversas espécies de mamíferos domésticos e selvagens. Os cães e os gatos além de outras espécies animais eliminam leptospiras pela urina, tendo importante papel epidemiológico na sua disseminação que prevalece em locais com falta de saneamento básico. A bactéria penetra no organismo pelo contato com água ou urina contaminada, pela pele lesada e mucosas. Vencendo as defesas naturais do organismo, se aloja principalmente no rim e no fígado. A vacinação e o manejo ambiental são as principais formas de prevenção.

Palavras-chave: zoonoses, leptospirose, brucelose, leishmaniose, raiva, toxoplasmose.

\title{
PRINCIPAL ZOONOSES IN SMALL ANIMALS: A BRIEF REVIEW
}

\begin{abstract}
With the close relationship between people and animals, zoonosis take an even more important role in public health. Among the main zoonoses can be highlighted rabies, leishmaniasis, canine brucellosis, Rocky Mountain spotted fever, toxoplasmosis and leptospirosis wich have different epidemiological and control aspects. Rabies is $100 \%$ fatal in animals and humans, causing acute encephalomyelitis, it is still considered a serious public health problem. Since the 1950s and 1960s, when there was a high number of cases of human rabies transmitted mainly by dogs in Brazil, it was observed growing in government activities, such as the implementation of the "Prevention National Program of Human Rabies" ( PNPR) in 1973, at national level, and then in 1983 the "Action Plan for the Elimination of Urban rabies the Cities of Latin America", developed by the Pan American Health Organization (PAHO). Some progress has been made in controlling the disease, reducing the number of human cases. In Brazil, in 2015, was reported only one case of human rabies. Canine Visceral Leishmaniasis (CVL) is expanding in Brazil. It is a zoonosis of importance to public health. The causative agent of canine visceral leishmaniasis is a protozoan of the genus Leishmania, transmitted by mosquitoes belonging to the family of sandflies. Dogs are the main reservoir of the disease and humans, accidental hosts. This disease in dogs brings a lot of controversy, since the Ministry of Health together with the Ministry of Agriculture Livestock and Supply (MAPA) created the Interministerial Ordinance No. 1426 which prohibits the treatment with medicaments recommended for the treatment of human unregistered products in MAPA, recommending euthanasia of infected or sick dogs. Canine Brucellosis is characterized as a chronic infectious anthropozoonosis that despite low incidence in the human population and its mild signs has great socioeconomic importance because it is the main cause of infertility in domestic canids worldwide and it is a zoonosis. It can infect humans in their work activities, especially in the case of shelter dogs. Brazilian Spotted Fever is caused by Gram negative bacteria, obligate intracellular, Rickettsia rickettsii. Its vector is the tick Amblyomma cajennense. With the proximity of urban and rural areas, the incidence of the disease in humans has increased, since exposure to vector and infected or sick animals is becoming more frequent. Rocky Mountain spotted fever has an acute evolution and its rapid diagnosis is important because it can be fatal in most cases, if the treatment is not rapidely iniciated. Toxoplasmosis is one of the most worldwide spread zoonoses, caused by the protozoan Toxoplasma gondii, which has three distinct genotypes. Its
\end{abstract}


definitive host is cat and other felines, and because of the increasing importance as a pet, there is need for further clarification about its transmission, especially, when there is the involvement of pregnant women. There are controversial and misconceptions about the direct contact with these animals and their transmission. Poor hygiene and eating raw foods are the main sources of contamination in humans and these health professional must guide the population as the essential hygiene measures to reduce its incidence. Leptospirosis is another zoonosis of worldwide distribution caused by the differents serovars of Leptospira interrogans that affects several species of domestic and wild mammals. The dog and cat eliminate leptospires in the urine, with important epidemiological role in the spread of this disease, which is prevalent in places with poor sanitation. The bacteria enter the body through contact with contaminated water or urine with the injured skin and mucous membranes, evading the body's natural defenses and staying mainly in the kidney and liver. Vaccination and environmental management are the main forms of prevention.

Keywords: zoonosis, leptospirosis, brucellosis, leishmaniasis, rabies, toxoplasmosis.

\section{ZOONOSIS PRINCIPALES EN PEQUEÑOS ANIMALES: UNA BREVE REVISÓN}

\section{RESUMEN}

Con la estrecha relación entre las personas y los animales, zoonosis toman un papel aún más importante en la salud pública. Entre las principales zoonosis se pueden destacar la rabia, la leishmaniasis, la brucelosis canina, la fiebre maculosa de las Montañas Rocosas, la toxoplasmosis y la leptospirosis que apresenteam epidemiológivos aspectos y control diferente entre ellos. La Rabia es 100\% mortal en los animales y los seres humanos, causando encefalomielitis aguda, todavía se considera un problema grave de salud pública. Desde la década de 1950 y 1960, cuando hubo un alto número de casos de rabia humana transmitida por perros, principalmente en Brasil, se observó crecimiento de las actividades gubernamentales, tales como la implementación del "Programa Nacional de Prevención de la rabia humana" ( PNPR) en 1973, a nivel nacional, y luego en 1983 el "plan de Acción para la eliminación de la rabia urbana de las ciudades de América Latina", desarrollado por la Organización Panamericana de la Salud (OPS). Se han hecho algunos avances en el control de la enfermedad, lo que reduce el número de casos humanos se han reportado un solo caso de rabia humana en Brasil en 2015. Leishmaniasis Visceral Canina (LVC) no se está expandiendo en Brasil. Es una zoonosis de importancia para la salud pública. El agente causante de la leishmaniasis visceral canina es un protozoo del género Leishmania, transmitida por mosquitos que pertenecen a la familia de los flebótomos. Los perros son los principales reservorios de la enfermedad primaria como seres humanos, huéspedes accidentales. Esta enfermedad en los perros trae mucha controversia, ya que el Ministerio de Salud, junto con el Ministerio de Agricultura, Ganadería y Abastecimiento (MAPA) creó la Orden Interministerial $\mathrm{N}^{\circ} 1426$, que prohíbe el trato con el uso humano o productos no registrados en el MAP, recomendar la eutanasia de los perros infectados o enfermos. La Brucelosis canina se caracteriza como un antropozoonosis infecciosa crónica que a pesar de la baja incidencia en la población humana y sus signos leves de esta especie, tiene una gran importancia socioeconómica, ya que es la principal causa de infertilidad en los cánidos domésticos en todo el mundo y es una zoonosis casual, incluso en el caso de la enfermedad en los perros pueden infectar a los seres humanos en sus actividades de trabajo, especialmente en el caso de los perros del refugio. La Fiebre de las Montanãs Rochosas es causada por bacterias gram negativas, intracelulares obligados, Rickettsia rickettsii. Su vector de la garrapata Amblyomma ixodideo cajennense. Con la proximidad de las zonas urbanas y rurales, la incidencia de la enfermedad en los seres humanos ha aumentado, ya que la 
exposición a vectores y animales infectados o enfermos es cada vez más frecuente. Fiebre de las Montañas Rocosas es la evolución aguda y su diagnóstico rápido es importante, ya que puede ser fatal en la mayoría de los casos, si la imposición del tratamiento rápidamente. Toxoplasmosis es una de las zoonosis propagación más en todo el mundo, causadas por el protozoo Toxoplasma gondii, que tiene tres genotipos distintos. Su gato huésped definitivo y otros felinos, y debido a la creciente importancia como animal de compañía, existe la necesidad de una mayor clarificación sobre su transmisión, sobre todo cuando existe la participación de las mujeres embarazadas. Hay polémica y conceptos erróneos sobre el contacto directo con estos animales y su transmisión. La falta de higiene y alimentos crudos alimenticios son las principales fuentes de contaminación en los seres humanos, y de esta manera profesional de la salud debe orientar a la población como las medidas de higiene esenciales para reducir su incidencia. Leptospirosis es otra zoonosis de distribución mundial causada por la bacteria Leptospira interrogans, y afecta a varias especies de mamíferos domésticos y salvajes. El perro y el gato eliminan leptospiras en la orina, con el papel epidemiológico importante en la propagación de esta enfermedad, que es frecuente en lugares con condiciones sanitarias deficientes. Las bacterias entran en el cuerpo a través del contacto con agua contaminada con la orina o la piel lesionada y las membranas mucosas, evadir las defensas naturales del cuerpo y permanecer principalmente en el riñón y el hígado. La vacunación y la gestión del medio ambiente son las principales formas de prevención.

Palabras clave: zoonosis, leptospirosis, brucelosis, leishmaniasis, rabia, toxoplasmosis.

\section{INTRODUÇÃO}

As doenças transmitidas dos animais para o ser humano são denominadas zoonoses, e estão distribuídas amplamente no mundo de acordo com as diferentes variações ambientais, socioeconômicas e culturais (1). A incidência destas vem aumentando gradativamente devido às constantes mudanças promovidas pelo ser humano no meio ambiente. Geralmente a maior disseminação de doenças se dá em regiões em que habitam populações mais carentes, com baixa renda e hábitos precários de higiene, propiciando uma maior proliferação de agentes patogênicos (2).

Devido ao estreitamento da relação humano-animal de companhia, os animais de estimação têm representado um maior risco na transmissão de algumas zoonoses, principalmente em casos em que esses animais exercem importante papel como portadores reservatórios e por transitarem em locais públicos, eliminando seus dejetos contaminados, facilitando a infecção de seres humanos bem como de outros animais (2). Além dos riscos proporcionados aos animais e seres humanos pelas zoonoses, há perdas em setores da saúde e agricultura, e grande prejuízo econômico (3).

A medicina veterinária está totalmente relacionada com a saúde pública, principalmente no que envolve a proteção aos alimentos e no combate e erradicação de zoonoses (3). Os aspectos epidemiológicos das doenças nos animais esclarecem como as enfermidades de caráter zoonótico podem chegar até os humanos. O presente estudo visa discorrer sobre as principais zoonoses transmitidas por animais de companhia principalmente no Brasil, e que acarretam grande impacto sócio-econômico-cultural para a população. Serão abordados os aspectos epidemiológicos, de controle e de impacto na saúde pública. Dentre as zoonoses que serão discutidas, estão: raiva, leishmaniose visceral canina, brucelose, toxoplasmose, leptospirose e febre maculosa.

A raiva é uma doença infecciosa, de caráter zoonótico e etiologia viral, que pode acometer todos os mamíferos, incluindo humanos, causando encefalomielite aguda com letalidade de cerca de $100 \%$, sendo, portanto, considerada ainda um grave problema de saúde pública (4). A Organização Mundial de Saúde Animal (OIE), em seu Código Sanitário para os

Lima MCF, Mittestainer JC, Rocha PB, Carvalho ER, Verotti BP, Pellicciari PR et. al. Principais zoonoses em pequenos animais: breve revisão. Vet. e Zootec. 2017 mar.; 24(1): 84-106. 
Animais Terrestres, lista a raiva na categoria das enfermidades comuns a várias espécies e se estima que ocorram cerca de 55.000 óbitos de raiva humana ao ano, a maioria transmitida por cães, principalmente na África e Ásia (5).

Alguns avanços foram obtidos no controle dessa doença, a exemplo da redução dos casos humanos e caninos devido, principalmente, às atividades direcionadas ao controle da raiva em cães (4), a partir da obrigatoriedade da vacinação antirrábica canina pelas prefeituras municipais, em 1973, pelo Ministério da Agricultura. Apesar de medidas profiláticas para seu controle, a raiva vem se mantendo endêmica em algumas regiões do Brasil, pois há diferentes espécies animais, com características biológicas do vírus da raiva menos estudadas, e pode-se citar o envolvimento cada vez maior dos morcegos na transmissão da doença para os animais domésticos e para os humanos. Assim, é importante estudar o comportamento de amostras do vírus da raiva, isoladas destas espécies, bem como a proteção conferida pelas vacinas utilizadas no controle da doença (6).

A Leishmaniose Visceral Canina (LVC) é uma zoonose causada por protozoário do gênero Leishmania e sua transmissão ocorre pela picada do mosquito flebotomíneo. Os cães são os reservatórios primários, porém o parasita pode se manter também em animais silvestres, e o ser humano e gatos são hospedeiros acidentais (7). Segundo dados da Organização Mundial de Saúde (OMS) a LVC é uma das principais zoonoses, com notificações de casos em 88 países e potencialmente letal para os humanos se não for devidamente tratada $(8,9)$.

A brucelose canina é uma antropozoonose infecciosa crônica de distribuição mundial. É causada principalmente pela Brucella canis, sendo a principal causa de infertilidade em canídeos domésticos em todo o mundo (10). Foi isolada pela primeira vez por Leland Carmichael em 1966 (11). Caracteriza-se pela sua transmissão venérea e também oral. Causa abortos tardios nas fêmeas, epididimite e prostatite em machos, levando à infertilidade em ambos os sexos, bem como linfadenite e discoespondilite como sinais extragenitais (12).

A toxoplasmose é uma das doenças mais prevalente mundialmente, acometendo as espécies de sangue quente, incluindo humanos. É causada pelo protozoário Toxoplasma gondii, e tem como hospedeiro definitivo os felinos, sendo humanos, mamíferos e aves hospedeiros intermediários (13).

Os felinos são os únicos que eliminam os oocistos nas fezes, pois fazem o ciclo enteroepitelial. Esses se tornam infectantes mediante temperatura e condições ambientais ideais para sua esporulação no meio ambiente. Os demais animais apenas transmitem o parasita se houver ingestão de sua carne contendo cistos com bradizoítos ou por via congênita a partir dos taquizoitos (14). As principais formas de infecção são, portanto, pela ingestão de tecidos contendo cistos com bradizoítos, ingestão de oocistos esporulados, e pela transmissão transplacentária (15).

Pode causar sinais neurológicos graves em pequenos animais, como ataxia, convulsões, paresia, além de comprometimento dos locais de replicação do parasita, como pulmões, fígado, olhos, sistema nervoso, fígado e tecido muscular esquelético (16). Considerando-se as formas de infecção, a maneira mais eficaz de combater a doença é pela orientação da população quanto aos hábitos de higiene como lavar as mãos, lavar hortaliças e frutas, não ingerir carne crua e/ou mal passada entre outros (17).

A leptospirose é outra zoonose de caráter mundial, prevalecendo em países da Ásia e América do Sul. É causada principalmente pelos sorovares da bactéria Leptospira interrogans, podendo afetar diversas espécies de mamíferos, incluindo cães e gatos, apesar da última espécie ser mais resistente. Entre os animais domésticos, o cão tem papel epidemiológico importante, eliminando leptospiras pela urina por períodos prolongados, contaminando o ambiente (18). O agente sobrevive em água de rios e ambientes úmidos e a infecção se dá por contato direto com a urina de animais infectados ou indireta a partir da água contaminada com a bactéria (19). Leptospiras patogênicas têm alta motilidade e 
capacidade de sobreviver e se multiplicar nos tecidos escapando dos mecanismos de defesa naturais (20).

Apesar dos cães serem hospedeiros de manutenção do sorovar Canicola, frequentemente, são hospedeiros acidentais do sorovar Icterohaemorrhagiae, cujos hospedeiros permanentes são os ratos, principalmente Rattus norvegicus (19).

Em humanos, ocorrem desde a forma assintomática, casos simulando quadro gripal, com febre, dores de cabeça e mialgia, a casos mais severos com sepse e falência múltipla de órgãos, incluindo disfunções hepáticas e renais associadas à hemorragia pulmonar (20).

Quanto aos animais domésticos, cães e cavalos apresentam a forma aguda da doença incluindo a síndrome ictero-hemorrágica. Outras espécies, principalmente animais de produção, apresentam a forma reprodutiva da doença, caracterizada por abortos e partos prematuros, natimortos e mumificação fetal, e outros problemas reprodutivos, levando a perdas substanciais (21).

Em condições experimentais, demonstrou-se que gatos podem adquirir leptospirose pela ingestão de roedores infectados, bem como pela ingestão de água contaminada. Embora não haja relatos de leptospirose clínica em condições naturais nessa espécie, estudos sorológicos conduzidos em diversas regiões apontaram frequências de soropositividade que chegam a $33,3 \%$ (22).

A Febre Maculosa Brasileira, conhecida também como febre petequial, foi reconhecida no Brasil pela primeira vez em São Paulo em 1929. Causada pela bactéria gram negativa, intracelular obrigatória Rickettsia rickettsii (23), é uma zoonose na qual o agente etiológico circula entre vetor e hospedeiro independente da participação de humanos. A maior incidência ocorre na região Sudeste do país, onde há maior ocorrência do carrapato, responsável pela transmissão, o Amblyomma cajennense. Ainda estão relacionados com a transmissão o Amblyomma aureolatum e Amblyomma dubitatum (24,25).

\section{REVISÃO DE LITERATURA}

\subsection{Raiva}

O vírus da raiva pertence ao Gênero Lyssavirus, família Rhabdoviridae e ordem Mononegavirales. Sua morfologia característica lembra o aspecto de uma "bala de revólver", com diâmetro médio de $75 \mathrm{~nm}$ e comprimento entre 100 e $300 \mathrm{~nm}$ (26). Trata-se de um vírus envelopado, composto por uma dupla membrana fosfolipídica, na qual são inseridas glicoproteínas denominadas "G", com aproximadamente $9 \mathrm{~nm}$ projetadas para o exterior. O nucleocapsídeo possui conformação helicoidal e é composto de um filamento único de RNA negativo, não segmentado, fortemente unido à nucleoproteína " $\mathrm{N}$ " e associados à presença de outras três proteínas estruturais $(\mathrm{P}, \mathrm{M}$ e L). A partícula completa do vírus rábico é chamada de vírion (27).

Acredita-se que o lissavírus dos quirópteros seja mais antigo que o dos carnívoros e que provavelmente o vírus da raiva tenha se originado por eventos de troca entre lissavírus de hospedeiros morcegos. O gênero Lyssavirus é atualmente subdividido em sete genótipos, sendo o genótipo " 1 " classificado como o vírus da raiva $(28,29)$.

Por ser envelopado é pouco resistente fora do organismo animal, sendo rapidamente inativado por agentes químicos (éter, clorofórmio, detergente, ácidos e álcalis fortes), aos agentes físicos (calor, luz ultravioleta) e às condições ambientais, como dessecação, luminosidade e temperatura excessiva (27).

A raiva está presente em todos os continentes, com exceção da Oceania e da Antártica, e de alguns países insulares que conseguiram sua erradicação, como o Reino Unido e Japão. Esta ampla distribuição pode ser atribuída à alta capacidade do vírus de se adaptar em 
diferentes reservatórios, sendo o genótipo tipo "1" o representante das amostras do vírus da raiva nas Américas (30).

Calcula-se na Ásia a ocorrência de 35.000 a 55.000 casos humanos de raiva anualmente e de, aproximadamente, 5.000 a 15.000 mortes na África. Na América Latina, o número de casos de raiva humana se limita a menos de 100 por ano, já na América do Norte e Europa, este número é inferior a 50 (31).

No Brasil, a raiva é considerada uma doença endêmica, com distribuição bastante heterogênea. Por suas características continentais e sua diversidade de fauna é de difícil erradicação, sendo que as regiões Nordeste e Norte apresentam maiores incidências da doença, enquanto que a região Sul é considerada uma área de raiva controlada, não apresentando novos casos desde 1990 (32).

A transmissão se dá pela inoculação percutânea do vírus contido na saliva de um animal infectado, pela mordedura, arranhadura ou lambedura, sendo também possível a infecção por feridas ou soluções de continuidade já existentes na pele, quando em contato com a saliva contaminada $(33,34)$. A possibilidade de sangue, leite, urina ou fezes conter uma quantidade de vírus suficiente para desencadear a raiva é remota. Há estudos experimentais e relatos de casos da transmissão por via aérea e oral, assim como em procedimentos médicos, a exemplo dos transplantes de córnea e outros, porém não apresentam significância epidemiológica importante no ciclo da doença (35-37).

$\mathrm{O}$ vírus se replica no local da inoculação, frequentemente o da mordedura, depois é conduzido via terminações nervosas motoras, aos nervos periféricos e pelas junções sinápticas célula-célula e/ou conexões intercelulares diretas, atinge o sistema nervoso central, de onde se dissemina via nervos periféricos de forma centrífuga para os tecidos não neuronais para todo organismo, tendo sido detectado seus antígenos na epiderme, retina, pulmões, miocárdio, mucosa gástrica, bexiga e uretra, porém o principal local de sua replicação são as glândulas salivares (38).

O período de incubação viral é variável, sendo a média em cães de três a oito semanas, com extremos variando de dez dias a seis meses, porém já foram relatados períodos mais longos. Pode se manifestar de formas variadas nas diferentes espécies atingidas, dependendo da localização da lesão. Porém podem ser observadas apresentações clássicas da doença, conhecidas como a forma furiosa e a forma paralítica (39).

No início do quadro, ou fase prodrômica, que antecede as manifestações clássicas, pode se observar sinais clínicos gerais e ainda pouco sugestivos, como apatia, inapetência, alterações de comportamento e incoordenação motora. A fase inicial pode ser seguida pela forma furiosa, frequentemente presente nos cães e caracterizada principalmente por um quadro de intensa agressividade, dificuldade de deglutição e intensa salivação, podem estar presentes ainda sinais de depressão, insônia e/ou febre. Na forma paralítica, o sinal mais observado é a paralisia da mandíbula e dos membros posteriores, podendo haver morte súbita por paralisia dos músculos respiratórios. A paralisia evolui por todo corpo na fase terminal e a morte acontece em alguns dias ( 7 a 10 dias), entretanto esta forma é comum em bovinos, secundária a lesões na medula, troco encefálico e cerebelo (40).

O vírus da raiva se mantém na natureza por meio de quatro ciclos interligados: o ciclo urbano, com os cães e gatos domésticos como transmissores, o ciclo silvestre, o ciclo aéreo, tendo os morcegos como vetores, e o ciclo rural, onde entram os herbívoros, principalmente bovinos e equinos. O ciclo urbano, com o cão doméstico como hospedeiro natural, tem grande importância zoonótica pela relação próxima deste com os seres humanos. Porém, o ciclo aéreo tem se apresentado como segundo principal meio de transmissão da doença para humanos (40).

Houve uma significativa diminuição do número de casos de raiva humana transmitidas por cães e gatos domésticos, por outro lado observa-se a constante participação dos morcegos na contabilidade do total dos casos nacionais, tendo como principal ocorrência o surto de 
raiva humana transmitida por morcegos hematófagos na região da Amazônia, em 2004 e 2005 (41). Recentemente, foi confirmado um caso de raiva humana na cidade de Corumbá-MS, com transmissão pela mordida de um cão de rua infectado e foram reportados 45 casos de raiva animal no estado, sendo este o único caso de raiva humana a nível nacional em 2015 (42).

Os morcegos encontrados no Brasil correspondem a quase 50\% dos morcegos encontrados em todo continente americano em um total de 144 espécies, sendo a grande maioria de hábito alimentar insetívoro, com 87 espécies; seguidos pelos frugívoros, com 35 espécies; nectarívoros com 14 espécies; carnívoros com 5 e hematófagos com 3 espécies. Entre elas, a espécie de morcego hematófago mais estudada é a Desmodus rotundus,por ser o principal transmissor da raiva aos herbívoros, pois é a espécie mais abundante e tem nesses animais a sua maior fonte de alimento $(43,44)$.

O encéfalo é o tecido de eleição para o diagnóstico de raiva, associado ao tronco e medula no caso de equinos. Os fragmentos a serem enviados para o laboratório são porções do cerebelo, córtex e hipocampo, já animais pequenos, como morcegos, gambás e saguis, devem ser encaminhados inteiros. Todas as amostras devem ser enviadas refrigeradas.

A detecção citológica dos corpúsculos de Negri é um rápido diagnóstico laboratorial, porém, apresenta baixa sensibilidade. A técnica de imunofluorescência direta (IFD) é amplamente utilizada como técnica de eleição para o diagnóstico de raiva por possuir alta sensibilidade e especificidade e pela sua rapidez. A IFD é acompanhada por um teste biológico pela inoculação em camundongos (45), de acordo com orientações da OMS.

Em humanos o diagnóstico sorológico também pode ser utilizado, onde a elevação de títulos de anticorpos soroneutralizantes no líquor de pacientes suspeitos é considerada diagnóstico, entretanto no caso de óbito é sempre recomendado o diagnóstico pela IFD e pela bioprova a partir da inoculação intracerebral em camundongos.

A prevenção da raiva tem se baseado na vacinação, com vacinas inativadas, e no controle de transmissores, principalmente de cães e gatos, com a eliminação de animais errantes. O controle de morcegos hematófagos é feito aplicando-lhes uma pasta com uma substância anticoagulante nos animais capturados, seguida de sua soltura para posterior disseminação do produto para demais animais da colônia (44).

\subsection{Leishmaniose Visceral Canina}

Existem dois grupos de leishmanias, um que causa a leishmaniose tegumentar (leishmaniose cutânea, mucocutânea e cutânea difusa) e, o grupo que causa a leishmaniose visceral. No Brasil, o agente etiológico da leishmaniose em sua forma visceral é a Leishmania chagasi (46). Os cães geralmente desenvolvem a forma visceral da doença. São infectados pela picada das fêmeas dos mosquitos da família dos flebotomíneos, do gênero Lutzomya, durante seu repasto sanguíneo. No Brasil, o principal vetor é a Lutzomia longipalpis, também conhecida como mosquito-palha, birigui ou tatuquiras. As formas imaturas dos vetores desenvolvem-se em locais úmidos, ricos em matéria orgânica e com baixa luminosidade (46).

As formas promastigotas se desenvolvem nos flebotomíneos e são inoculadas no hospedeiro vertebrado quando o vetor se alimenta, transformando-se em amastigota. É fagocitada pelos macrófagos e se disseminam. O período de incubação é variável, entretanto é longo entre 3 a 7 meses, podendo chegar a mais de um ano.

Os cães com leishmaniose visceral podem apresentar perda de peso, poliúria, polidipsia, debilidade muscular, depressão, vômito, diarreia, tosse, epistaxe, espirro e melena (47). Dentre os achados de exame físico, merecem destaque a linfoadenomegalia, caquexia, hipertermia, esplenomegalia, onicogrifose, uveíte e conjuntivite. A principal causa de morte dos cães com LVC é a insuficiência renal. As manifestações cutâneas na LVC ocorrem entre $50 \%$ a $90 \%$ dos cães infectados. O sinal dermatológico mais comum é a dermatite esfoliativa 
com escamas esbranquiçadas, normalmente mais evidentes na cabeça, orelhas e extremidades (48).

Anteriormente, até a década de 90, a região Nordeste correspondia a 90\% dos casos de LV do país. Porém, a doença expandiu para as regiões Centro Oeste, Sul, Sudeste e Norte, modificando esta situação. No estado de São Paulo, foi diagnosticada em 1998 com o primeiro caso de LVC no município de Araçatuba (49).

O diagnóstico da LVC pode ser realizado a partir de exames parasitológicos, sorológicos e moleculares. O diagnóstico parasitológico ocorre pela demonstração de amastigotas no aspirado de linfonodos, de medula óssea ou em impressões dérmicas coradas com Giemsa e Wright, fornecendo um diagnóstico definitivo. Os testes sorológicos evidenciam a presença de anticorpos circulantes, mas podem falhar, por exemplo, no período pré- patente e antes da soroconversão (50). Pode realizar-se também, os métodos moleculares, como PCR de aspirados da medula óssea e linfonodos (51).

O tratamento da LVC pode propiciar uma melhora dos sinais clínicos da doença, porém, o prognóstico é muito variável, e na maioria das vezes os casos são recorrentes. Além disso, o tratamento não impede que o cão se mantenha infectante para o vetor, ou seja, o cão continua como reservatório (52), apesar de com carga parasitaria menor. Em 11 de julho de 2008, criou-se a Portaria Interministerial do Governo Federal, de número 1.426, que proíbe os médicos veterinários de realizarem tratamento da LVC em cães infectados ou doentes, com produtos de uso humano para o tratamento da doença, ou não registrados no MAPA e recomenda-se o sacrifício dos cães infectados ou doentes (53). Assim sendo, qualquer médico veterinário que desrespeitar a portaria, ou ainda que omita a notificação, poderá sofrer penalidade por parte do Conselho Federal de Medicina Veterinária, já que a LVC é uma doença de notificação compulsória (54).

No Brasil, muitos proprietários de cães se recusam a eutanasiar o animal positivo para LVC. Este fato é relatado por profissionais ligados ao setor público e responsáveis pelo controle da doença. Desta forma, há profissionais recomendando protocolos de tratamento, com medicamentos alternativos com o que tem se observado melhora no quadro clínico. Enfatiza-se a importância de se discutir com o proprietário prós e contras do tratamento, pois se trata de um sério problema de saúde pública (55), considerando-se que mesmo com o tratamento, o animal continua sendo uma fonte de infecção, pois não ocorre a eliminação completa do parasita, apenas a melhora aparente do animal.

Apesar da polêmica a respeito da vacina, ela é uma ferramenta importante e pode ser utilizada associada a outros métodos de controle como a utilização de coleiras repelentes, principalmente nas regiões hiperendêmicas (56).

\subsection{Brucelose}

Apesar dos relatos de casos de brucelose em cães causados por quatro das seis espécies do gênero Brucella, três delas (Brucella melitensis, Brucella suis, Brucella abortus) produzem infecções apenas ocasionais, enquanto $B$. canis é a espécie de maior importância epidemiológica. B. canis é um cocobacilo gram-negativo que se diferencia das demais espécies do gênero Brucella (exceto Brucella ovis) na medida em que forma colônias rugosas (57). Ela se desenvolve em meios de cultura comum, incluindo agar triptose e não necessita de gás carbônico para o seu isolamento. Ela ocorre em todas as raças de cães, bem como em humanos.

A principal forma de contágio com Brucela canis é a partir do contato com a mucosa genital, oronasal e conjuntival, mas pode também contaminar os cães por meio de lesões de pele. O modo mais comum de transmissão é a venérea, embora os cães também possam se infectar quando expostos à secreção vaginal, placenta, urina, fetos e natimortos e secreções provenientes de aborto (58). Os machos eliminam o agente pelo sêmen. Apesar de ambos os 
sexos excretarem bactérias na urina, as concentrações na urina dos machos são mais elevadas, atingindo entre $10^{3}$ e $10^{6}$ bactérias $/ \mathrm{mL}$ de urina (59). Para o ser humano a transmissão se da principalmente pelo contato com o agente.

Por esta razão, a urina do macho é mais perigosa como via de transmissão do que a da fêmea. A excreção de bactérias pela urina inicia em 4 a 8 semanas após a infecção. A concentração bacteriana no leite contaminado é alta, entretanto alguns autores não consideram uma importante via de transmissão, uma vez que os filhotes se infectam no útero (58). Podese pensar que a partir do leite pode ocorrer contaminação ambiental podendo ser importante do ponto de vista epidemiológico.

A infecção também pode ocorrer via fômites, tais como vasilhas de água e alimentos, equipamentos e roupas. $\mathrm{O}$ agente pode sobreviver no ambiente por vários meses em condições de alta umidade, temperaturas baixas, e abrigadas da luz solar, especialmente se houver a presença de material orgânico. B. canis pode resistir à secagem e sobreviver em poeira (60), podendo se considerar, portanto, a sua resistência frente às condições ambientais.

Após sua penetração, são fagocitadas por macrófagos e outras células fagocíticas de defesa, atingindo órgãos linfáticos (gânglios linfáticos e baço) e órgãos genitais, onde se multiplicam. A bacteremia ocorre de 1 a 4 semanas após a infecção, persistindo por pelo menos 6 meses. A seguir pode ocorrer bacteremia intermitente, por até 64 meses (58). Inicialmente o organismo se sensibiliza e só após 4 a 6 semanas desenvolve anticorpos humorais das classes IgM e a seguir IgG.

A orquite e epididimite são as principais manifestações em machos. Pode haver ainda atrofia testicular, infertilidade e linfoadenopatia generalizada, tanto nos machos como nas fêmeas (10). Nestas, ocorre aborto e metrite, com possibilidade de disseminação, sendo isoladas do sangue e outros órgãos, além dos genitais. Nos machos, as brucelas podem se alojar na próstata e serem eliminadas juntamente com a urina por período de tempo prolongado, sendo importante via de transmissão para os humanos e sério problema em saúde pública (11).

O diagnóstico definitivo da brucelose canina se dá pelo isolamento bacteriano do microorganismo, no entanto, isso nem sempre é possível (60). Os vários diagnósticos sorológicos variam em sensibilidade e especificidade, conduzindo a falsos positivos e negativos, dependendo da fase da doença e o antígeno ou o método utilizado (61). Os dados clínicos e da anamnese devem ser usados em associação com a sorologia e bacteriologia para se chegar a um diagnóstico definitivo (60).

Os anticorpos contra o agente podem ser detectados após duas semanas de infecção. Eles são produzidos em resposta aos antígenos presentes na parede bacteriana e também às suas proteínas citoplasmáticas. Os métodos utilizados para a detecção variam em sensibilidade, especificidade e complexidade. Atualmente há vários métodos sorológicos utilizados na prática: prova do antígeno tamponado acidificado (Card Test); reação de soroaglutinação lenta (SAL); prova do 2-mercaptoetanol (2-ME); fixação de complemento (FC), ELISA e imunodifusão em gel de ágar. Para a detecção de anticorpos contra B. canis e B. ovis, é recomendada a técnica de imunodifusão em gel de ágar.

O cultivo bactériano é a melhor maneira de confirmar a infecção por $B$. canis e o melhor método para o diagnóstico precoce de infecção em cães que não receberam tratamento com antibióticos. Infelizmente, um resultado negativo não confirma a ausência de infecção, pois pode ter havido cura da doença, uma vez que as bactérias podem estar temporariamente ausentes no tecido cultivado.

O material mais utilizado para cultura é o sangue, uma vez que, além da fácil obtenção, é "estéril", o que permite que as culturas não sejam contaminadas. Meios aeróbicos são usados para a hemocultura, incubando - se por nove dias a $37^{\circ} \mathrm{C}$. Subculturas em ágar triptose, geralmente adicionando polimixina $\mathrm{B}$ e bacitracina aos meios para inibir o 
crescimento de possíveis contaminantes, devem ser realizadas nos dias 3, 6 e 9 de incubação (62).

Frequentemente, o sêmen é contaminado, assim como as secreções vaginais durante o estro e após abortos. Uma alta concentração de micro-organismos pode ser encontrada na placenta, apesar dos fetos abortados poderem não conter o agente. Pesquisas mostram que amostras de urina foram positivas para o cultivo bacteriano mesmo em animais nos quais bactérias não foram encontradas no sangue, entretanto, este teste é mais confiável em machos, uma vez que a urina das fêmeas pode estar frequentemente contaminada por outros patógenos (63). Os melhores órgãos para isolamento são gânglios linfáticos, próstata, baço, medula e, às vezes, fígado e testículos (64).

Por se tratar de bactéria intracelular, os antibióticos não conseguem alcançá-la adequadamente. Além disso, é sensível a relativamente poucos antibióticos (65). Muitos deles têm sido testados, sozinhos ou em combinação, porém nenhum foi $100 \%$ eficaz na eliminação do agente. A bacteremia pode ser eliminada em alguns casos e não se encontrar resposta sorológica, especialmente, daqueles contra a parede celular bacteriana. No entanto, as bactérias podem permanecer viáveis nos tecidos na maioria dos casos (66).

Frequentemente, os títulos reaparecem tardiamente após a infecção e em diferentes momentos após o término do tratamento. Nas fêmeas, pode ocorrer muitas vezes durante o estro ou após situações estressantes. Mesmo as fêmeas não tratadas podem dar à luz, mas os filhotes nascem infectados, mantendo assim a doença nos casos de canis. Os machos normalmente permanecem estéreis devido às lesões testiculares, mas, mesmo assim, podem continuar a transmitir a doença. A resposta ao tratamento é melhor quando há associação com outro antibiótico. O tratamento de 105 cães com tetraciclina oral $(30 \mathrm{mg} / \mathrm{kg})$ duas vezes ao dia, durante 28 dias, e estreptomicina $(20 \mathrm{mg} / \mathrm{kg})$ uma vez por dia, por 14 dias consecutivos revelou negatividade na sorologia de 81 animais (67).

Todos os novos animais (machos ou fêmeas) que entram no canil devem ser criteriosamente examinados e mantidos em quarentena por 8 a 12 semanas (10). Machos e fêmeas utilizados como reprodutores devem ser submetidos a teste sorológico semestralmente para minimizar o risco de infecção e propagação da doença (10). A incidência da doença em seres humanos não é exatamente conhecida, pois apesar da $B$. canis afetar humanos, há poucos relatos da doença, que ocorre geralmente a partir do contato direto com material de abortos ou de secreções durante o estro (68). Foram relatados casos de infecção relacionados às atividades laboratoriais (69). A doença inicia com febre prolongada, gânglios linfáticos aumentados, faringite, dor nas articulações tremores e perda de peso, entretanto, a clínica é muito polimorfa com quadro clínico muito variado sendo o diagnóstico laboratorial importante para elucidação (70). As pessoas infectadas respondem rapidamente a tratamentos com antibióticos, incluindo as tetraciclinas isoladamente, ou em combinação com estreptomicina ou ampicilina.

\subsection{Toxoplasmose}

A toxoplasmose é uma doença de caráter multissistêmico, causada pelo protozoário Toxoplasma gondii, agente intracelular que parasita, praticamente, todos os mamíferos e as aves. O ciclo reprodutivo do $T$. gondii inclui a presença de taquizoítos, que ocorrem na fase aguda, de bradizoítos que se localizam em cistos teciduais e são detectados na fase crônica da doença, e de esporozoítos que estão presentes em oocistos, formados no trato digestivo de felinos (71).

Os felinos são os hospedeiros definitivos pois são os únicos que desenvolvem o ciclo enteroepitelial. Os oocistos são eliminados pelas suas fezes, e esporulam no ambiente, sendo então infectantes, e também mais resistentes às condições ambientais. Humanos, demais mamíferos e aves são hospedeiros intermediários, nos quais ocorre apenas a reprodução 
assexuada do protozoário, sendo encontrado, portanto, na forma de bradizoítos ou de taquizoítos.

É uma doença que traz prejuízos devido às grandes perdas econômicas nos animais de produção, principalmente em ovinos. É causada principalmente pela ingestão de carne crua e/ou mal cozida contendo cistos teciduais, ou pela ingestão de água e alimentos contaminados pelos oocistos provenientes das fezes de felinos. Outra forma de transmissão é a vertical, que se dá da mãe para o feto durante a gestação pela passagem trasplacentária de taquizoítos.

A infecção nos felinos ocorre pelo seu hábito de predador, a partir da caça de roedores ou passeriformes que contenham cistos de bradizoítos, ou pela ingestão direta de taquizóitos presentes na carne crua e/ou mal passada, ou pela ingestão de oocistos presentes no ambiente. Três a 10 dias após a ingestão de tecido contendo cistos, os felinos começam a eliminar os oocistos. Após 3 a 5 dias no ambiente, com temperatura e condições ideais para seu desenvolvimento, é que os oocistos se tornam infectantes. A eliminação ocorre por 7 a 15 dias pelas fezes em grande quantidade. Normalmente esse fato ocorre apenas após a primo infecção, adquirindo resistência e tornando-se imunes praticamente por toda a vida (17).

Quando o hospedeiro intermediário ingere os cistos ou oocistos, sua parede se rompe liberando as formas infectantes no intestino. Ocorre rápida multiplicação dentro das células e passagem para a forma evolutiva de taquizoítos, que acabam por romper estas células e se difundem para o tecido linfoide do trato intestinal, se disseminando para outras partes do organismo (17).

Os sinais clínicos que se desenvolvem após a infecção dependem da necrose tecidual que lesa e destrói as células devido à ação intracelular do agente. Os locais de maior replicação são pulmões, fígado, olhos, sistema nervoso, fígado e tecido muscular esquelético (16). As infecções agudas ocorrem de forma generalizada, podendo levar o animal a óbito em um curto período de tempo, e os principais sinais clínicos são vômito e diarreia, linfoadenopatia, icterícia, uveíte, convulsões, opistótomo entre outros. Na infecção crônica, há presença de sinais neuromusculares, incluindo paresia, paralisia, ataxia, convulsão, em alguns casos miosite. Caso a transmissão ocorra via intrauterina, os filhotes podem apresentar miosite e/ou radiculoneurite (17).

Em cães, há uma maior prevalência da doença conforme aumenta a sua idade devido as maiores chances de exposição, estando muitas vezes associada ao vírus da cinomose ou outras enfermidades imunossupressoras $(72,73)$.

Os felinos normalmente não apresentam sinais clínicos, porém, se apresentarem doenças imunossupressoras concomitantes, podem desenvolver quadros de diarreia, hepatite, pneumonia, inflamação ocular e distúrbios neurológicos, sendo que a doença é mais grave em gatos recém-nascidos que podem desenvolver ascite, uveíte, depressão, letargia, encefalite, hipotermia podendo levar a óbito (16).

O diagnóstico da toxoplasmose pode ser feito por testes diretos e indiretos, sendo visualizado o parasita desde esfregaço de conjuntiva ocular como por material proveniente de punção de linfonodo e fígado. A interpretação dos exames deve ser feita de forma correta para diferenciar infecção e doença. O diagnóstico mais utilizado é o sorológico. A sorologia pareada com intervalo de 15 dias entre uma amostra de soro e outra, com elevação do título em 4 vezes ou mais, determina se animal está infectado. Apesar de haver a possibilidade de encontrar oocistos nas fezes dos felinos, este método não é o mais confiável, pois a quantidade liberada nas fezes pode ser muito pequena e não detectada e os oocistos não se diferenciam de outros protozoários, havendo a necessidade de técnicas de esporulação.

A sorologia se baseia na detecção de $\operatorname{IgG}$ e $\operatorname{IgM}$ específicas, sendo que o rápido aumento de $\operatorname{IgM}$ sugere infecção recente, enquanto a IgG detecta a cronicidade da infecção. Há vários testes sorológicos que são recomendados como a reação de imunfluorescência indireta - RIFI, ELISA e a reação de aglutinação modificada - MAD, entre outras (74). 
O tratamento para a toxoplasmose é possível tanto em animais como em humanos, visando evitar a progressão da doença. O tempo de duração vai depender do estado imunológico. Os fármacos, de modo geral, apenas suprimem a multiplicação do protozoário, mas não são efetivos em inativa-los (74).

Em pequenos animais, o tratamento instituído geralmente é com clindamicina por este ultrapassar a barreira hemato-encefálica e vascular $(16,74)$ conferindo melhora clínica do paciente em até 24 horas após inicio do tratamento, com restabelecimento do apetite e do funcionamento dos nervos cranianos (16). A dose recomendada é de $25 \mathrm{mg} / \mathrm{kg}$ a cada 12 horas por 14 a 30 dias (74). Não há medicamento disponível para a eliminação de cistos teciduais (17).

A prevenção contra a toxoplasmose humana é a forma mais eficaz de combatê-la, sendo fundamental incentivar hábitos de higiene, não ingestão de carne crua e/ou mal passada, lavagem de frutas e vegetais, manter as caixas de areia dos felinos sempre limpas, usando luvas para a retirada diária das fezes para se evitar esporulação, lavar as mãos após manipulação de carne crua, ingerir apenas leite pasteurizado, alimentar os felinos com produtos industrializados, e se possível, evitar que os felinos saiam de casa. É interessante também o controle populacional de gatos errantes para diminuir a contaminação ambiental por oocistos (75).

\subsection{Leptospirose}

A leptospirose é uma zoonose de ampla distribuição mundial, causada por diferentes sorovares de Leptospiras que são espiroquetas de aproximadamente $0.1 \mu \mathrm{m}$ de diâmetro por 6$20 \mu \mathrm{m}$ de comprimento, e incluem espécies saprófitas e patogênicas. São micro-organismos, anaeróbios e móveis. Possuem, em cada uma de suas extremidades, dois flagelos, podendo estar acompanhados de um gancho típico. O encontro do Subcomitê de Taxonomia realizado em Quito, Equador, em 2007 concedeu o status de espécie, pois anteriormente as leptospiras eram consideradas como genomoespécies 1, 3, 4 e 5, o que resultou em uma família compreendendo 13 espécies patogênicas de Leptospira (76). Mais de 250 sorovares, identificados com base em antígenos de superfície, são conhecidos, e cada um deles tem um hospedeiro preferencial. Os sorovares predominantes na infecção canina parecem ser o canicola, adaptado à espécie, e o Icterohaemorrhagiae, que tem o rato doméstico (Rattus norvegicus) como principal reservatório e o cão como hospedeiro acidental (77).

Cada sorovar é adaptado a um ou mais mamíferos como hospedeiro primário ou reservatório. Este hospedeiro pode abrigar o patógeno sem demonstrar sinais clínicos, além de disseminar o micro-organismo pela urina por meses após a infecção (78). As bactérias se alojam nos túbulos renais do animal reservatório e são excretadas pela urina. Há também o hospedeiro secundário ou acidental, que tende a desenvolver a doença clínica e, ou se curam, ou vão a óbito. O cão serve de hospedeiro acidental para a Leptospira interrogans sorovar Icterohaemorragiae, cujos reservatórios são comumente roedores, gambás e animais de fazenda (79).

As leptospiras podem ser transmitidas diretamente entre hospedeiros pelo contato com urina, transferência placentária, mordidas ou ingestão de tecidos infectados, uma vez que o micro-organismo penetra as mucosas ou pele lesada. A transmissão indireta ocorre com a exposição de animais ou humanos susceptíveis a ambientes contaminados com urina de animais infectados. Água contaminada é a forma mais comum de disseminação, uma vez que ambientes alagados favorecem a sua sobrevivência.

Após penetração da pele ou mucosas, multiplicam com a entrada na corrente sanguínea. Isso dá início à fase leptospirêmica, que dura até 7 dias com rápida replicação bacteriana e lesão tecidual. Após essa fase há a invasão de vários órgãos, incluindo o rim, baço, fígado e sistema nervoso central, além de olhos e trato reprodutivo. Devido a multiplicação e produção

Lima MCF, Mittestainer JC, Rocha PB, Carvalho ER, Verotti BP, Pellicciari PR et. al. Principais zoonoses em pequenos animais: breve revisão. Vet. e Zootec. 2017 mar.; 24(1): 84-106. 
de citocinas e células inflamatórias há lesão tecidual, inicialmente células endoteliais e, mais tardiamente, os rins e fígado (80).

Após essa fase ocorre colonização renal, principalmente no epitélio dos túbulos renais com liberação de citocinas, recrutamento de células inflamatórias e nefrite aguda; hepática, com necrose centrolobular e obstrução do ducto biliar, podendo causar icterícia. A lesão endotelial origina edema tissular e coagulação intravascular disseminada (CID) nos primeiros dias. Em cães pode haver manifestação pulmonar com tosse e distrição respiratória. Essas alterações estão associadas à hemorragia devido à lesão endotelial e vasculite (78).

Os sinais clínicos são variáveis e estão associados ao sorovar envolvido. Sorovares adaptados à espécie hospedeira, como é o caso do sorovar canicola em cães, podem levar a infecção inaparente, enquanto outros sorovares podem levar a quatro síndromes no cão: ictérica, hemorrágica, urêmica (doença de Stuttgart) e reprodutiva. Tipicamente há ocorrência de febre, icterícia, vômito e diarreia, podendo evoluir para CID, uremia por falência renal, hemorragias e morte (76). Em felinos, apesar de serem mais resistentes, o sorovar mais comumente encontrado parece ser o Pomona $(81,82)$, embora estudos conduzidos na França mostrem prevalência do sorovar Canicola (83). Gatos com altos títulos de anticorpos têm tendência a desenvolverem doença renal e eliminarem leptospiras na urina (84). Nessa espécie não há sinais clínicos agudos, embora $48 \%$ dos animais soropositivos apresentem poliuria e polidipsia (85).

Durante o estágio inicial da doença, pode haver leucopenia seguida de leucocitose com trombocitopenia, o que pode explicar a hemorragia. Durante a leptospirose crônica, os parâmetros hematológicos são normais, havendo necessidade da dosagem de enzimas hepáticas para investigação de hepatite crônica, além de sorologia e cultura bacteriológica (85) a partir do sangue ou da urina (78). Detecção de anticorpos específicos pelo teste de microaglutinação microscópica (MAT) e imunoensaios como o ELISA são comumente utilizados, além de microscopia de campo escuro e PCR. O MAT é o mais utilizado por possuir a vantagem de ser específico para sorovares (ou ao menos sorogrupos), porém não diferencia anticorpos resultantes de infecção ou vacinação. $O$ animal é considerado positivo para leptospirose se houver um título na MAT $\geq 400$, associado com sinais clínicos, ou um aumento de quatro vezes na sorologia pareada.

O tratamento do paciente com leptospirose compreende tratar as manifestações renais ou hepáticas da doença, além do uso de antimicrobianos via oral como a doxiciclina a $5 \mathrm{mg} / \mathrm{kg} / \mathrm{BID}$ ou amoxicilina $22 \mathrm{mg} / \mathrm{kg} / 12 \mathrm{~h}$, ou ampicilina $22 \mathrm{mg} / \mathrm{kg} / \mathrm{IV}$, e deve ser iniciado assim que haja suspeita da doença para eliminar a bacteremia e, consequentemente, o risco zoonótico (80).

O controle e a prevenção começam, idealmente, limitando o contato dos animais de estimação com animais-reservatório e com água contaminada. O controle de roedores é importante para a prevenção da exposição dos animais às leptospiras e, consequentemente, para diminuir os riscos de transmissão do agente aos seres humanos (22). Devem-se retirar vasilhas de água e comida durante a noite para evitar a presença de roedores.

Tendo em vista que a leptospirose é disseminada por diferentes espécies de animais selvagens e as leptospiras podem viver por longos períodos em água limpa, a vacinação canina com vacinas contendo os sorovares mais importantes para a espécie esta indicada pelo menos anualmente, lembrando que a proteção é sorovar específica.

\subsection{Febre Maculosa}

A febre maculosa é uma zoonose bacteriana causada pela bactéria Ricketsia ricktsii, de ampla distribuição. No Brasil, a maioria dos casos ocorre na Região Sudeste, devido a maior concentração do carrapato transmissor, com casos esporádicos em outros estados brasileiros, em especial no Sul do país (86). É uma doença com caráter sazonal com maior incidência nos 
meses de julho a setembro, o que coincide com o aumento de ninfas do carrapato $A$. cajennense, seu principal vetor. Essa sazonalidade é mais marcante no interior do estado, com pequena variação do numero de casos na região metropolitana de São Paulo, durante todo o ano (25).

Cavalos e capivaras tem grande importância na transmissão da febre maculosa por serem os principais reservatórios do carrapato transmissor. Equinos mantidos em pastos sujos, com presença de rios ou córregos e vegetação alta tem ainda maior predisposição à infestação pelo A. cajennense (25).

Ressalta-se o aumento do numero de casos da doença em humanos, na Região Sudeste do país a partir de 2000 até o ano de 2005. De 2005 até junho de 2015, a notificação de casos não apresentou grandes alterações. Segundo o Centro de Vigilância Epidemiológica, CVE, no estado de São Paulo em 2000 foram notificados apenas 41 casos e em 2005, 90 casos. De 2005 a 2014, foram notificados entre 62 e 104 casos no estado, e em 2015 até o mês de julho já haviam sido notificados 21 casos da doença no estado (87). Verifica-se que a doença temse tornado mais importante, havendo a necessidade de maior vigilância e ações de controle.

A transmissão da $R$. ricketsii se da pela picada do carrapato em qualquer fase, sendo mais frequente na infecção humana a transmissão pelas ninfas, que tem uma picada menos dolorida, diminuindo o incomodo no momento do repasto sanguíneo (23). O carrapato ixodideo, se alimenta uma vez em cada estagio de sua vida, fazendo isso em vários hospedeiros, podendo transmitir a doença caso esteja infectado. Para que haja transmissão é necessário no mínimo de 8 a 10 horas de fixação do carrapato na pele do paciente humano ou do animal (23).

A transmissão pode ocorrer também no momento da retirada do carrapato que está fixado na pele, de forma inadequada, promovendo o seu esmagamento com refluxo de conteúdo estomacal no momento da retirada, facilitando a inoculação da bactéria (23). A contaminação do ixodideo transmissor pode ocorrer de duas formas: a primeira é pela fixação e repasto em mamíferos infectados, principalmente, na fase de larva e ninfa, a segunda forma é a transmissão transestadial e ovariana, podendo ocorrer ainda à transmissão venérea, quando carrapatos adultos copulam (88).

A $R$. ricketsii infecta o hospedeiro a partir da picada do carrapato e se multiplica em células endoteliais de vasos de menor calibre. Ocorre lesão das células endoteliais, promovendo ativação plaquetaria e do sistema de coagulação. Há diminuição dos níveis de trombina III e o aumento da degranulação do fibrinogênio. Origina-se assim uma vasculite necrosante progressiva, devido à ativação da coagulação, quimiotaxia celular levando a necrose vascular. A necrose juntamente com o extravasamento sanguíneo e a ativação da coagulação são responsáveis pela trombocitopenia, observada em animais naturalmente infectados (89).

O período de incubação varia entre 2 a 14 dias após fixação do carrapato. O primeiro sinal clínico em cães e humanos naturalmente infectados é a febre, que aparece geralmente 2 a 3 dias após a fixação do carrapato. Outros sinais são êmese, diarreia, sinais oculares como congestão de esclera e uveite, linfadenomegalia, edema, necrose cutânea, icterícia, hepatomegalia, petéquias e equimoses, rigidez articular e sinais neurológicos como hiperestesia, tetraparesia e sinais vestibulares (90).

O diagnóstico é baseado nos sinais clínicos associando-se com os resultados hematológicos sugestivos da infecção. O animal pode apresentar no inicio da doença hemograma com leucopenia discreta, que logo é substituída por leucocitose, geralmente caracterizada como leucocitose por estresse com um mínimo desvio a esquerda. Observa-se também uma queda no numero de plaquetas, que na maioria dos casos não é inferior a 75.000 plaquetas por microlitro de sangue. Achados bioquímicos são principalmente a hipoalbuminemia, hiperbilirrubinemia discreta, aumento discreto de ureia e creatinina, sendo mais acentuados nos estágios terminais da doença (91). Deve haver associação com histórico 
epidemiológico no caso de doença em humanos, como, por exemplo, o contato com animais com carrapato.

Para confirmação da doença a principal ferramenta é a sorologia, sendo eficiente o método de ELISA e imunofluorescência indireta. A PCR é mais utilizada para detecção da doença em humanos, mas é também eficiente para utilização em cães (92). É utilizada também para a pesquisa de DNA do parasita na hemolinfa de carrapatos.

$\mathrm{O}$ seu tratamento é realizado com o uso de antibióticos bacteriostáticos, como as tetraciclinas, sendo a doxiciclina a mais recomendada (92). A duração do tratamento é de no mínimo 7 dias. O uso de cloranfenicol também se mostrou eficiente, devendo ser evitado em cães com menos de 6 meses (93).

Não há vacina para proteção de cães, nem de humanos. O melhor método de profilaxia é evitar acesso a áreas endêmicas, realizar a inspeção para detecção de carrapatos em cães, assim como de roupas, e do próprio corpo, após exposição a áreas que possam conter o carrapato transmissor (94). O ideal é que a observação do corpo ocorra a intervalos regulares de tempo para se evitar a inoculação do agente. Sugere-se a utilização de botas em atividades de campo e também que se coloque o cano das meias sobre a calça, e que se utilize fita gomada dupla, evitando-se assim a subida de carrapatos pelas pernas.

\section{CONSIDERAÇÕES FINAIS}

A presente revisão reuniu informações sobre as zoonoses de animais de companhia, de impacto na saúde pública. A conscientização e a prática da guarda responsável, por meio da vacinação e cuidados da saúde de cães e gatos, além do bem estar animal, tem um papel essencial na prevenção das zoonoses, pois os animais de estimação conquistaram espaço no seio das famílias e a relação entre eles e humanos é muito estreita. $\mathrm{O}$ fato de compartilharem o mesmo ambiente, é um fator condicionante para a ocorrência das zoonoses. Programas de educação em saúde são fundamentais para o esclarecimento da população visando à prevenção dessas zoonoses.

\section{REFERÊNCIAS}

1. Vasconcellos SA. Zoonoses e saúde pública: riscos causados por animais exóticos. Biológico. 2001;63:63-5.

2. Lima AM, Alves LC, da Glória Faustino MA, de Lira NM. Percepção sobre o conhecimento e profilaxia das zoonoses e posse responsável em pais de alunos do préescolar de escolas situadas na comunidade localizada no bairro de Dois Irmãos na cidade do Recife (PE). Rev Cienc Saude Coletiva. 2010;2:15.

3. Pfuetzenreiter MR, Zylbersztajn A, Pires FDA. Evolução histórica da medicina veterinária preventiva e saúde pública. Cienc Rural. 2004;34(5):1661-8.

4. Ministério da Saúde (BR). Secretaria de vigilância em saúde. Guia de vigilância epidemiológica. Caderno 13: Raiva. 7a ed. Brasília: Ministério da Saúde; 2009. (série A Normas e Manuais Técnicos).

5. Knobel DL, Cleaveland S, Coleman PG, Fèvre EM, Meltzer MI, Miranda ME, et al. Reevaluating the burden of rabies in Africa and Asia. Bull World Health Organ. 2005;83(5):360-8. 
6. Schneider MC, Souza LM, Moraes NB, Diaz RC. Controle da raiva no Brasil de 1980 a 1990. Rev Saude Publica. 1996;30(2):196-203.

7. Costa CHN. How effective is dog culling in controlling zoonotic visceral leishamniasis? A critical evaluation of the science, politics and ethics behind this public health policy. Rev Soc Bras Med Trop. 2011;44(2):232-42.

8. Julião FS, Souza BM, Freitas DS, Oliveira LS, Laranjeira DF, Dias-Lima AG, et al. Investigação de áreas de risco como metodologia complementar ao controle da leishmaniose visceral canina. Pesqui Vet Bras. 2007;27(8):319-24.

9. Romero GA, Boelaert M. Control of visceral leishmaniasis in Latin America: a systematic review. PLoS Negl Trop Dis. 2010;4(1):584.

10. Hollet RB. Canine brucellosis: outbreaks and compliance. Theriogenology. 2006;66(3):575-87.

11. Carmichael LE. Abortion in 200 Beagles. J Am Vet Med Assoc. 1966;149(8):1126.

12. Wanke MM. Canine brucellosis. Anim Reprod Sci. 2004;82(83):195-207.

13. Avila VPF. Toxoplasmose felina: revisão de literatura. Porto Alegre: Universidade Rural do Semi-Árido - UFERSA; 2009. p.1-27.

14. Millar PR. Soroprevalência de anticorpos anti-Toxoplasma gondii em trabalhadores de um matadouro-frigorífico na cidade de Palmas, Paraná, Brasil [dissertação]. Niterói: Universidade Federal Fluminense; 2005.

15. Marques JM, Isbrecht FB, Lucas TM, Guerra IMP, Dalmolin A, Da Silva RC, et al. Detecção de anticorpos anti-Toxoplasma gondii em animais de uma comunidade rural do Mato Grosso do Sul, Brasil. Semina Cienc Agrar. 2009;30(4):889-98.

16. Galvão ALB, Vasconsellos AL, Navarro IT, Bresciani KDS. Aspectos da toxoplasmose na clínica de pequenos animais. Semina Cienc Agrar. 2014;35(1):393-410.

17. Prado AAF, De Almeida GF, Gontijo LS, Torres MLM. Toxoplasmose: o que o profissional da saúde deve saber. Encicl Biosfera. 2011;7(12):1-30.

18. Modolo JR, Langoni H, Padovani CR, Shimabukuro FH, Mendonça AO, Vitoria C, et al. Investigação soroepidemiológica de leptospirose canina na área territorial urbana de Botucatu, São Paulo, Brasil. Braz J Vet Res Anim Sci. 2006;43(5):598-604.

19. Caldart ET, Constantino C, Pasquali AKS, Benitez NA, Hamada FN, Dias RCF, et al. Zoonoses em cães e gatos atendidos em Projeto de Controle de Natalidade: Toxoplasma gondii, Leishmania spp. e Leptospira spp., sorodiagnóstico e epidemiologia. Semina Cienc Agrar. 2015;36(1):253-66.

20. Marinho M, Táparo CV, Oliveira-Júnior IS, Perri SHV, Cardoso TC. Tissue apoptosis in mice infected with Leptospira interrogans serovar Icterohaemorrhagiae. J Venom Anim Toxins Incl Trop Dis. 2015;21:22. doi: 10.1186/s40409-015-0022-y. 
21. Martins G, Lilenbaum W. The panorama of animal leptospirosis in Rio de Janeiro, Brazil, regarding the seroepidemiology of the infection in tropical regions. BMC Vet Res. 2013;9:237.

22. Brasil AWL, Parantoni RN, Feitosa TF, Vilela VLR, Alves CJ, Vasconcellos AS, et al. Anticorpos anti-Leptospira spp. em gatos do semiárido do Estado da Paraíba. Semina Cienc Agrar. 2014;35(6):3215-20.

23. Del Fiol FS, Junqueira FM, Rocha MCP, Toledo MI, Barberato Filho S. A febre maculosa no Brasil. Rev Panam Salud Publica. 2010;27(6):461-6.

24. Ribeiro MD, Furtado MA, Ferraudo AS, Cesario M, da Andrade Morraye M. Fatores ambientais envolvidos na epidemiologia da febre maculosa no estado de São Paulo. Hygeia. 2013;9(16):103.

25. Katz G, Neves VL, Angerami RN, Nascimento EM, Colombo S. Situação epidemiológica e importância da febre maculosa no Estado de São Paulo. Bepa, Bol Epidemiol Paul. 2009;6(69):4-13.

26. Van Regenmortel MHV, Fauquet CM, Bishop DHL, Carstens EB, Estes MK, Lemon SM, et al. Virus taxonomy: classification and nomenclature of viruses. Seventh Report of the International Committee on Taxonomy of Viruses. California: Academic Press; 2000. p.563-83.

27. Iseni F, Barge A, Baudin F, Blondell D, Ruigrok RWH. Characterization of rabies virus nucleocapsids and recombinant nucleocapsid-like structures. J Gen Virol. 1998;79(Pt 12):2909-19.

28. Badrame H, Tordo N. Host switching in lyssavirus history from the chiroptera to the carnivore ordens. J Virol. 2001;75(17):8096-104.

29. Tordo N, Poch O. Structure of rabies vírus. In: Campbell JB, Charlton KM. Rabies. Boston: Kluwer Academic Publishers; 1988. p.25-45.

30. Bernardi F, Nadim-Davis SA, Wandeler AI, Armstrong J, Gomes AAB, Lima FS, et al. Antigenic and genetic characterization of rabies viruses isolated from domestic and wild animals of Brazil identifies the hoary fox as a rabies reservoir. J Gen Virol. 2005;86(Pt 11):3153-62.

31. Belotto AJ. Situação epidemiológica da raiva: panorama mundial. In: Anais do Simpósio Internacional Programa de Treinamento "Controle de zoonoses e as interações homemanimal”; 2001; São Paulo. São Paulo: Embu; 2001. p.26-8.

32. Reichmann MLAB. Considerações sobre áreas geográficas de raiva controlada: experiência do estado de São Paulo, Brasil, 1995 a 2003. In: Anais do Seminário Internacional de Raiva; 2003; São Paulo. São Paulo: Instituto Pasteur; 2003. p.28.

33. Fundação Nacional da Saúde. Guia de vigilância epidemiológica. Brasília: Funasa; 2002. p.673-704. v.II. 
34. Reichmann MD, Pinto HD, Arantes MB, Santos MB, Viaro O, Nunes VD. Educaçäo e promoção da saúde no Programa de Controle da Raiva. do 2000 (No. 5). São Paulo: Instituto Pasteur; 2000. (Manual técnico; n 5).

35. Hellenbrand W, Meyer C, Rasch G, Steffens I, Ammon A. Cases of rabies in Germany following organ transplantion. Euro Surveill. 2005;10(2):213-6.

36. Kusne S, Smilack J. Transmission of rabies virus from an organ donor four transplantion recipients. Liver Transplant. 2005;11(10):1295-7.

37. Constantine DG. Rabies transmission by nonbite route. Public Health Rep. 1962;77(4):287-9.

38. Tsiang H. Pathophysiology of rabies virus infection of nervous system. Adv Virus Res. 1993;42:375-412.

39. Baer GM, Lentz TL. Rabies pathogenesis to the central nervous system. In: Baer GM. The natural history of rabies. 2nd ed. Boca Raton: RCR Press; 1991. p.105-20.

40. Corrêa WM, Corrêa CN. Enfermidades infecciosas dos mamíferos domésticos. São Paulo: Varela; 1983.

41. Rosa ES, Kotait I, Barbosa TF, Carrieri ML, Brandão PE, Pinheiro AS, et al. Battransmitted human rabies outbreaks, Brazilian Amazon. Emerg Infect Dis. 2006;12(8):1197-202.

42. Ministério da Saúde (BR) [Internet]. Brasília: Ministério da Saúde; 2015 [cited 2015 Aug 10]. Available from: http://portalsaude.saude.gov.br/index.php/o-ministerio/principal/leiamais-o-ministerio/752-secretaria-svs/vigilancia-de-a-a-z/raiva/11431-situacao-

epidemiologica-dados.

43. Taddei VA. Sistemática de quirópteros. Bol Inst Pasteur. 1996;1(2):3-15.

44. Ministério da Agricultura, Pecuária e Abastecimento (BR). Controle da raiva dos herbívoros. Brasília: MAPA/SDA/DAS; 2005. (Manual técnico).

45. Reichmann MLAB, Pinto HBF, Nunes VFP. Controle de populações animais de estimação. São Paulo: Instituto Pasteur; 2000. (Manual técnico; nº 6).

46. Camargo JB, Troncarelli MZ, Ribeiro MG, Langoni H. Leishmaniose visceral canina: aspectos de saúde pública e controle. Clin Vet. 2007;12(71):86-92.

47. Nelson RW, Couto CG. Medicina interna de pequenos animais. 2a ed. Rio de Janeiro: Guanabara Koogan; 2001. p.1037-8.

48. Marcondes CB, Pirmez C, Silva ES, Laurentino-Silva V, Steindel M, Santos AJ, et al. Levantamento de leishmaniose visceral em cães de Santa Maria e municípios próximos, Estado do Rio Grande do Sul. Rev Soc Bras Med Trop. 2003;36(4):499-501.

49. Camargo-Neves V. A leishmaniose visceral americana no Estado de São Paulo: situação atual. Bepa, Bol Epidemiol Paul. 2007;4(48):12-4. 
50. Ikeda-Garcia FA, Marcondes M. Métodos de diagnóstico da leishmaniose visceral canina. Clin Vet. 2007;12(71):34-42.

51. Camargo JB, Langoni H, Troncarelli MZ, Machado JG, Lucheis SB, Padovani CR. Performance of IFAT, ELISA, direct parasitological examination and PCR on lymph node aspirates for canine visceral leishmaniasis diagnosis. J Venom Anim Toxins Incl Trop Dis. 2010;16(3):414-20.

52. Baneth G, Shaw SE. Chemotherapy of canine leishmaniasis. Vet Parasitol. 2002;106(4):315-24.

53. Ministério da Saúde (BR). Portaria Interministerial $\mathrm{n}^{\circ} 1.426$, de 11 de Julho de 2008. Brasília: Ministério da Saúde; 2008 [cites 2015 Aug 14]. Available from: http://www.cfmv.org.br/portal/legislacao/outras_normas/porta1426.pdf.

54. Amaral T. Leishmaniose visceral canina: um alerta para saúde pública. Rev Cães Gatos. 2009;123:20-5.

55. Feijão AMM, Lima, JWO, Vieira, F, Nations, MK. O significado do cachorro para a família: estudo qualitativo sobre a estratégia de eliminação de cães infectados com Leishmania para o controle do calazar. 37o Congresso da Sociedade Brasileira de Medicina Tropical. Rev Soc Bras Med Trop. 2001;34 Supl 1:230.

56. Dantas-Torres F, Brandão-Filho SP. Visceral leishmaniasis in Brazil: revisiting paradigms of epidemiology and control. Rev Inst Med Trop. 2006;48(3):151-6.

57. Berthelot X, Garin BB. Brucelloses canines. Point Vet. 1993;25:125-9.

58. Carmichael LE, Green EG. Canine brucellosis. In: Greene CE. Infectious diseases of the dog and cat. Philadelphia: WB Saunders; 1990. p.573.

59. Serikawa T, Muraguchi T, Yamada J. Long-term observation of canine brucellosis: excretion of Brucella canis into urine of infected male dogs. Jikken Dobutsu. 1981;30(1):7-14.

60. Johnson CA, Walker RD. Clinical signs and diagnosis of Brucellacanis infection. Compend Contin Educ PractVet. 1992;14(763/767):770-2.

61. Carmichael LE, Joubert, JC. A rapid slide agglutination test for the serodiagnosis of Brucellacanis infection that employs a variant (M) organism as antigen. Cornell Vet. 1987;77(1):3-12.

62. Nicoletti P. Diagnosis and treatment of canine brucelosis. In: Kirk RW. Current veterinary therapy X. Philadelphia: WB Saunders; 1989. p.1317-20.

63. Serikawa T, Muraguchi T, Nakao N, Irie Y, Erikawa T, Muraguchi T. Significance of urine-culture for detecting infection with Brucella canis in dogs. Jpn. J Vet Sci. 1978;40:353-5.

64. Weber A, Schliesser T. Serologischer und kultureller nachweis von Brucella canis bei beagle-hundeneiner versuchstierhaltung. Zentralbl Veterinarmed. 1975;22:403-10. 
65. Nicoletti P, Chase A. The use of antibiotics to control canine brucellosis. Compend Contin Educ Pract Vet. 1987;9:106366.

66. Wanke MM, Monachesi NE, Loza ME, Rutter B, Baldi PC, Fossati CA. Determinacion de anticuerpos contra proteinas citoplasmáticas de Brucella por ELISA para la detección de casos crónicos de brucelosis canina. Selec Vet. 2000;8:308-11.

67. Nicolleti P. Further studies on the use of antibiotics in canine brucellosis. Compend Contin Educ Pract Vet. 1991;13:944.

68. Shin SJ, Carmichael LE. Canine brucelosis caused by Brucella canis. In: Carmichael L. Recent advances in canine infectious diseases. Ithaca, NY: International Veterinary Information Service; 1999.

69. Godoy AM, Neves J, Peres JN, Barg L. Sobre um caso de infecção humana por Brucella canis em laboratório. Arq Esc Vet. 1979;31:141-5.

70. Munford RS, Weaver RE, Patton C, Feeley JC, Feldman RA. Human disease caused by Brucella canis. A clinical and epidemiologic study of two cases. J Am Med Assoc. 1975;231(12):1267-9.

71. Bresciani KD, Da Costa AJ, Navarro IT, Toniollo GH, Sakamoto CA, Arantes TP, et al. Toxoplasmose canina: aspectos clínicos e patológicos. Semina Cienc Agrar. 2008;29(1):189-202.

72. Giraldi JH, Bracarense APFRL, Vidotto O, Tudury EA, Navarro IT, Batista TN. Sorologia e histopatologia do Toxoplasma gondii e Neospora caninum em cães portadores de distúrbios neurológicos. Semina Cienc Agrar. 2002;23(1):9-14.

73. Baldotto SB, Oliveira PP, Antunes RM, Oliveira PD, Feitosa PP, Pereira DA. Toxoplasmose com repercussão neurológica: relato de caso. Rev Cient Eletronica Cienc Soc FAIT. 2014;5:1-34.

74. Moretti LD, Silva AV, Ribeiro MG, Paes AC, Langoni H. Toxoplasma gondii genotyping in a dog co-infected with distemper virus and ehrlichiosis rickettsia. Rev Inst Med Trop Sao Paulo. 2006;48(6):359-63.

75. Langoni H, Silva AV, Cabral KG, Cunha ELP, Cutolo AA. Prevalência da Toxoplasmose em gatos dos estados de São Paulo e Paraná. Braz J Vet Res Anim Sci. 2001;38(5):243-4.

76. Adler B, Moctezuma AP. Leptospira and leptospirosis. Vet Microbiol. 2010;140(34):287-96.

77. Brod CS, Aleixo JAG, Jouglard SDD, Fernandes CPH, Teixeira JLR, Dellagostin AO. Evidência do cão como reservatório da leptospirose humana: isolamento de um sorovar, caracterização molecular e utilização em inquérito sorológico. Rev Soc Bras Med Trop. 2005;38(4):294-300.

78. Goldstein RE. Canine Leptospirosis. Vet Clin North Am Small Anim Pract. 2010;40(6):1091-101. doi:10.1016/j.cvsm.2010.07.008.

Lima MCF, Mittestainer JC, Rocha PB, Carvalho ER, Verotti BP, Pellicciari PR et. al. Principais zoonoses em pequenos animais: breve revisão. Vet. e Zootec. 2017 mar.; 24(1): 84-106. 
79. Freire IMA, Varges A, Lilenbaum W. Níveis séricos de uréia e creatinina em cães com leptospirose aguda determinada por amostras do sorogrupo Icterohaemorrhagiae. Cienc Rural. 2008;38(4):1172-5.

80. Paes AC. Leptospirose canina. In: Megid J, Ribeiro MG, Paes AC. Doenças infecciosas em animais de produção e de companhia. Rio de Janeiro: Roca; 2016. p.356-377.

81. Jamshidi S, Akhavizadegan MA, Bokaie S, Maazi N, Ghorban ALI A. Serologic study of feline leptospirosis in Tehran, Iran. Iran J Microbiol. 2009;1(2):32-6.

82. Markovich JE, Ross L, McCobb E. The prevalence of leptospiral antibodies in free roaming cats in Worcester County, Massachusetts. J Vet Internal Med. 2012;26(3):688-9.

83. Luciani O. Receptivité et sensibilité du chat aux leptospires [thesis]. Nantes, France: École Nationale Vétérinaire de Nantes; 2004.

84. Rodriguez J, Blais MC, Lapointe C, Arsenault J, Carioto L, Harel J. Serologic and Urinary PCR Survey of Leptospirosis in healthy cats and in cats with kidney disease. J Vet Int Med. 2014;28(2):284-93.

85. Baldwin CJ, Atkins CE. Leptospirosis in dogs. Compend Contin Educ Pract Vet. 1987;9:499-507.

86. Neves MAT, Guerschman TM, Sakata UM. Febre maculosa na região do grande abc (Região Metropolitana de São Paulo, Brasil), de 1998 a 2011. Bol Epidemiol CVE [Internet]. 2012 [cited 2015 Aug 10];2(11):189-95. Available from: http://www.cve.saude.sp.gov.br/boletim/txt/bol1112_febre_maculosa.htm.

87. Secretaria da Saúde (BR). Febre Maculosa. São Paulo; 2015 [cited 2015 Aug 15]. Available from: http://www.cve.saude.sp.gov.br/.

88. Sexton DJ, Keith SK. "Rocky Mountain spotted fever". Med Clin North Am. 2002;86(2):351-60.

89. Grindem CB, Breitschwerdt EB, Perkins PC, Cullins LD, Thomas TJ, Hegarty BC. Platelet-associated immunoglobulin (antiplatelet antibody) in canine Rocky Mountain spotted fever and ehrlichiosis. J Am Anim Hosp Assoc. 1999;35(1):56-61.

90. Anderson BE, McDonald GA, Jones DC, Regnery RL. A protective protein antigen of Rickettsia rickettsii has been tandemly repeated, near identical sequences. Infect Immun. 1990;58(9):2760-9.

91. Davidson MG, Breitschwerdt EB, Walker DH, Nassisse MP, Sussman WE. Identification of rickettsiae in cutaneous biopsy specimens from dogs with experimental Rocky Mountain spotted fever. J Vet Intern Med. 1989;3(1):8-11.

92. Labruna MB, Horta MC, Aguiar DM, Cavalcante GT, Pinter A, Gennari SM, et al. Prevalence of Rickettsia infection in dogs from the urban and rural areas of Monte Negro Municipality, Western Amazon, Brazil. Vector Borne Zoonotic Dis 2007;7(2):249-55. 
93. Nicholson WL, Gordon R, Demma LJ. Spotted fever group rickettsial infection in dogs from eastern Arizona. How long has it been there? Ann NY Acad Sci. 2006;1078:519-22.

94. Nicholson WL, Paddock CD, Demma L, Traeger M, Johnson B, Dickson J, et al. Rocky Mountain spotted fever in Arizona: documentation of heavy environmental infestations of Rhipicephalus sanguineus at an endemic site. Ann NY Acad Sci. 2006;1078:338-41.

Recebido em: 04/07/2016

Aceito em: 24/02/2017 